\title{
Learning Vector Quantization 3 (LVQ3) and Spatial Fuzzy C- Means (SFCM) for Beef and Pork Image Classification
}

\author{
Jasril $^{1}$, Suwanto Sanjaya ${ }^{2}$ \\ ${ }^{1,2}$ Departement of Informatics Engineering, UIN Sultan Syarif Kasim Riau \\ 1,2J1. HR. Soebrantas No.155 KM 18 Panam, Pekanbaru - Riau \\ Email: ${ }^{1}$ suwantosanjaya@uin-suska.ac.id, 2jasril@uin-suska.ac.i
}

\begin{tabular}{|c|c|}
\hline Article Info & ABSTRACT \\
\hline Article history: & $\begin{array}{l}\text { Base on some cases in Indonesia, meat sellers often mix beef and pork. } \\
\text { Indonesia is a predominantly Muslim country. Pork is forbidden in }\end{array}$ \\
\hline Received May $13^{\text {th }} 2018$ & Islam. In this research, the classification of beef and pork image was \\
\hline Revised Jun $16^{\text {th }} 2018$ & performed. Spatial Fuzzy C-Means is used for image segmentation. \\
\hline Accepted Jul 05 2018 & GLCM and HSV is used as a feature of segmentation results. LVQ3 is \\
\hline Keywords: & variation of learning rate values and window values. The learning rate \\
\hline Beef and pork image & values used is $0.0001 ; 0.01 ; 0.1 ; 0.4 ; 0.7 ; 0.9$ and the window values \\
\hline Classification & used is $0.0001 ; 0.4 ; 0.7$. The training data used is $90 \%$ of the total data, \\
\hline Image Processing & and the testing data used is $10 \%$. Maximum epoch used is 1000 \\
\hline Learning Vector Quantization & iterations. Based on the test results, the highest accuracy was $91.67 \%$. \\
\hline Spatial Fuzzy C-Means & Copyright $@ 2018$ Puzzle Research of Data Technology \\
\hline \multicolumn{2}{|l|}{ Corresponding Author: } \\
\hline \multicolumn{2}{|c|}{ Suwanto Sanjaya, } \\
\hline \multicolumn{2}{|c|}{ Departement of Informatics Engineering, } \\
\hline \multicolumn{2}{|c|}{ UIN Sultan Syarif Kasim Riau, } \\
\hline \multicolumn{2}{|c|}{ J1. Soebrantas No.155 KM 18 Panam, Pekanbaru, Riau. } \\
\hline \multicolumn{2}{|c|}{ Email: suwantosanjaya@uin-suska.ac.id } \\
\hline
\end{tabular}

\section{PENDAHULUAN}

Salah satu bahan pangan pokok yang mengandung protein cukup tinggi adalah daging sapi dimana selain dikonsumsi oleh kebutuhan rumah tangga, daging sapi juga sebagai bahan baku industri pengolahan, hotel dan restoran. Pada saat ini kebutuhan daging sapi di Indonesia meningkat setiap tahunnya. Khusus di provinsi Riau menurut Kepala Dinas Peternakan Provinsi Riau, kebutuhan daging sapi sekitar 100 ekor perhari dan meningkat 30\% menjelang hari raya (www.tribunnews.com, 31 Juli 2013). Sedangkan konsumsi daging sapi secara nasional juga terus meningkat. Harga daging sapi di pasar dalam negeri bulan November 2015 ratarata sebesar Rp.110.283/kg. Jika dibandingkan dengan bulan Oktober 2015, harga tersebut mengalami penurunan sebesar $0,06 \%$. Selanjutnya, jika dibandingkan dengan harga pada bulan Nopember 2014, terjadi peningkatan sebesar $11,17 \%$. Namun jika dilihat secara keseluruhan perkembangan harga daging sapi domestik November 2012-2015 berdasarkan sumber dari (Badan Pusat Statistik, 2015), harga daging sapi domestik setiap tahun nya mengalami kenaikan.

Tingginya permintaan daging sapi menjadi celah bagi pedagang nakal untuk melakukan pencampuran daging sapi dengan daging babi (oplosan). Kasus pengoplosan daging ini terjadi di berbagai daerah di Indonesia antara lain pada tahun 2012 terjadi di Jombang (www.surabaya.okezone.com, 14 Des 2012) dan Depok (www.republika.co.id, 20 Des 2012). Sedangkan pada tahun 2013 terjadi di Semarang (www.republika.co.id, 11 Juli 2013) dan Bogor (www.jpnn.com, 20 April 2013). Menurut situs online (Republika, 2016) pada 28 Januari 2016 lalu bahwa mahalnya harga dan kebutuhan akan daging sapi begitu tinggi, namun tidak sesuai dengan daya beli masyarakat, maka timbul banyak kasus pemalsuan dan penyampuran daging sapi dengan daging babi atau disebut juga daging oplosan. Pada penelitian ini daging oplosan yang dimaksud bukan yang sudah diolah menjadi makanan tetapi daging oplosan campuran antar daging sapi mentah dan daging babi mentah.

Oleh karena itu guna melindungi konsumen dari berbagai motif penipuan yang dilakukan oleh pedagang yang tidak bertanggung jawab diperlukannya suatu teknologi yang mudah, cepat dan memiliki akurasi yang baik didalam membedakan daging sapi, daging babi. Salah satu teknologi yang dapat diterapkan di bidang informatika yaitu dengan pemanfaatan pengolahan citra. 
Beberapa penelitian di bidang pengolahan citra daging sapi dan babi telah dilakukan diantaranya penelitian kualitas daging babi menggunakan metode transformasi Fourier dan lacunarity [1]. Begitu juga penelitian untuk mengklasifikasikan daging babi dan ayam kalkun menggunakan metode linear discriminant analysis (LDA) dan HSV [2]. Sedangkan [3] membahas tentang sistem pengenalan citra daging babi dan citra sapi menggunakan penggabungan metode Back Propagation Neural Network (BPNN) dan Principal Component Analysis (PCA) sebagai pengekstraksi ciri dari sebuah citra. Selain itu [4] melakukan identifikasi citra untuk mengidentifikasi jenis daging sapi dengan menggunakan metode HSV (Hue, Saturation, Value) dan transformasi wavelet haar. Penelitian terakhir yang dilakukan [5] mengembangkan sistem pengenalan daging sapi dan babi menggunakan penggabungan metode GLCM, HSV dan metode klasifikasi Learning Vector Quantization (LVQ). Pada penelitian ini diperoleh tingkat akurasi tertinggi sebesar 94,81\%.

Metode Spatial Fuzzy C-Means (SFCM) dipilih sebagai metode segmentasi karena menurut [6] menunjukkan hasil segmentasi yang baik dan efektif. Metode HSV dipilih sebagai metode ekstraksi ciri warna menurut [7], metode HSV merupakan metode ekstraksi ciri warna yang memiliki tingkat akurasi terbaik dibandingkan RGB. Sedangkan metode GLCM dipilih sebagai metode ekstraksi ciri tekstur karena menurut [8] ekstraksi GLCM 4 arah $\left(0^{\circ}, 45^{\circ}, 90^{\circ}\right.$, dan $\left.135^{\circ}\right)$ dengan jarak d=1 memiliki akurasi terbaik dalam mengklasifikasi mammogram yaitu sebesar $81,1 \%$ dan khusus pada arah $0^{0}$ akurasi klasifikasi diperoleh sebesar 100\%. Sedangkan metode klasifikasi Learning Vector Quantization 3 (LVQ3) dipilih karena berdasarkan penelitian [9] algoritma LVQ3 lebih baik dibandingkan dengan LVQ1 yakni nilai rata-rata akurasi dengan LVQ3 adalah 95.2\% sedangkan nilai rata-rata akurasi dengan LVQ1 adalah 88\%.

\section{METODOLOGI}

Pada penelitian ini dipaparkan langkah-langkah yang dilakukan dalam penyelesaian permasalahan penelitian ini. Hal ini bertujuan agar proses penyelesaian penelitian ini berjalan sesuai dengan apa yang diharapkan.

\section{Pengumpulan Data}

Teknik dalam pengumpulan data yang dilakukan yaitu dengan mengumpulkan terlebih dahulu sampel daging yang diperoleh secara langsung dari pasar tradisional yakni pasar bawah Pekanbaru. Sampel daging yang terkumpul selanjutnya dilakukan proses pengambilan atau akuisisi citra menggunakan kamera. Akuisisi citra dilakukan dengan tujuan untuk menentukan data citra yang dibutuhkan pada penelitian ini. Untuk terpenuhinya data citra yang dibutuhkan, maka terdapat beberapa aspek yang harus terpenuhi dalam pengambilan citra daging. Adapun beberapa aspek tersebut adalah sebagai berikut.

a. Pengambilan data citra terdiri dari tiga jenis citra yaitu citra daging sapi, citra daging babi dan citra daging oplosan.
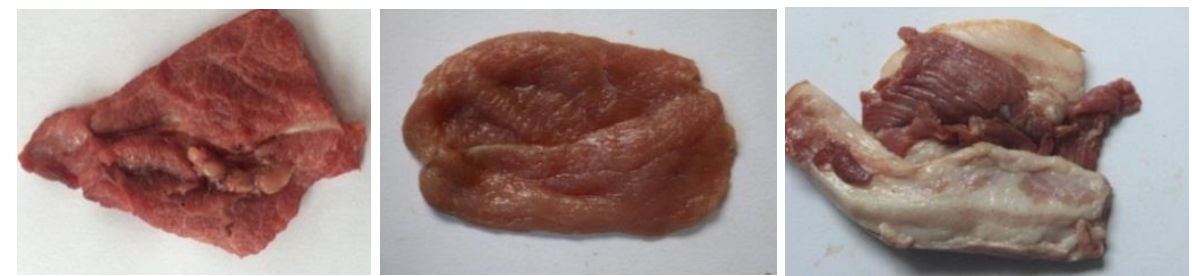

Gambar 1. Daging Sapi (Kiri), Babi (Tengah), Oplosan (Kanan)

b. Untuk jenis citra daging oplosan, sampel jenis daging oplosan komposisi daging terdiri dari daging sapi dan babi, dimana persentase perbandingan komposisi antara daging sapi dan daging babi 50\% sapi dan 50\% babi.

c. Teknik dalam pengambilan setiap data citra terdiri dari pengambilan data citra daging menggunakan background berwarna putih.

d. Pengambilan data dilakukan dengan menggunakan kamera DSLR Canon EOS 70D dan jarak antara kamera dengan objek daging yaitu sebesar $15 \mathrm{~cm}$.

e. Pengambilan data citra dilakukan dengan memposisikan atau memperkirakan posisi objek daging berada pada area tengah citra.

Berdasarkan beberapa aspek tersebut maka didapatkan data citra yang dibutuhkan dalam penelitian ini. Adapun jumlah keseluruhan data yang dibutuhkan pada penelitian ini yaitu sebanyak 120 citra daging, dimana terdiri dari 60 citra daging sapi, 50 citra daging babi dan 10 citra daging oplosan. Untuk selanjutnya citra daging oplosan dikelompokkan kedalam citra daging babi karena sudah termasuk daging yang tidak halal. 
Pembagian data latih dan data uji dilakukan secara acak. Data latih yang digunakan sebesar 90\% dan data uji sebesar $10 \%$ dari 120 citra. Komposisi data latih yaitu $90 \%$ dari citra daging sapi atau 54 citra daging sapi, 90\% dari citra daging babi atau 45 citra daging babi, $90 \%$ dari citra daging oplosan atau 9 citra daging oplosan. Total data latih adalah 108 citra. Begiru juga komposisi data uji yaitu $10 \%$ dari masing-masing jenis citra daging. Total data uji adalah 12 citra.

\section{Analisa Proses Klasifikasi}

Ada beberapa tahapan yang harus dilakukan untuk menghasilkan hasil klasifikasi yaitu proses ekstraksi ciri seluruh citra, pembagian data latih dan data uji, pelatihan, dan pengujian. Tahapan proses klasifikasi dapat dilihat pada Figure 2.

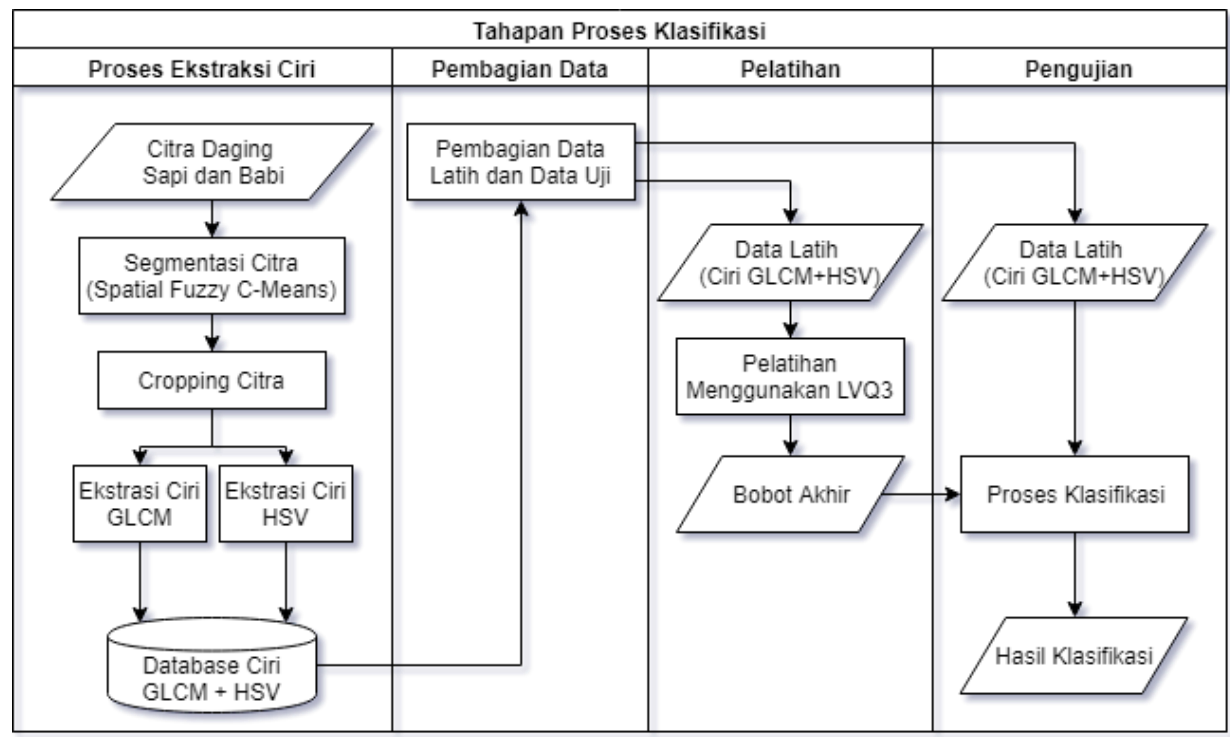

Gambar 2. Tahapan proses klasifikasi

Tahapan segmentasi citra (SFCM) [6] adalah sebagai berikut:

a. Membaca masukan Nilai RGB citra

b. Inisialisasi dan set nilai-nilai atribut SFCM seperti Cluster $(c)=2, m=2, T=100, e=1 \times 10^{-4}, P_{0}=0, t=1$

c. Pembentukan matriks partisi awal atau derajat keanggotaan acak $\left(\mathrm{u}_{\mathrm{ik}}\right)$ antara 0 sampai 1

d. Normalisasi nilai $u_{i k}$

$$
\mathrm{u}_{\mathrm{ik}}=\frac{\mathrm{u}_{\mathrm{ik}}}{\mathrm{Q}_{\mathrm{k}}}, \mathrm{i}=1,2 . ., \mathrm{n} ; \mathrm{k}=1,2, . ., \mathrm{c} ; \text { dimana } \mathrm{k} \text { adalah banyak cluster }
$$

dimana nilai $\mathrm{Q}_{\mathrm{k}}$ dapat dicari menggunakan persamaan berikut:

$$
\mathrm{Q}_{\mathrm{k}}=\sum_{\mathrm{i}=1}^{\mathrm{n}} \mathrm{u}_{\mathrm{ik}} \text {, dimana } \mathrm{k}=1,2, \ldots, \mathrm{c}
$$

e. Penentuan Pusat Cluster

$$
v_{k j}=\frac{\sum_{i=1}^{n} u_{i k} m_{x_{i j}}}{\sum_{i=1}^{n} u_{i k}{ }^{m}}, k=1,2, \ldots, c ; j=1,2, \ldots, m
$$

f. Perubahan Derajat Keanggotaan $\left(\mathrm{u}_{\mathrm{ik}}\right)$

$$
\mathrm{u}_{\mathrm{ik}}=\frac{\left[\sum_{\mathrm{j}=1}^{\mathrm{m}}\left(\mathrm{x}_{\mathrm{ij}}-\mathrm{v}_{\mathrm{kj}}\right)^{2}\right]^{\frac{-1}{\mathrm{~m}-1}}}{\sum_{\mathrm{k}=1}^{\mathrm{c}}\left[\sum_{\mathrm{j}=1}^{\mathrm{m}}\left(\mathrm{x}_{\mathrm{ij}}-\mathrm{v}_{\mathrm{kj}}\right)^{2}\right]^{\frac{-1}{\mathrm{~m}-1}}}, \mathrm{i}=1,2, \ldots, \mathrm{n} ; \mathrm{k}=1,2, \ldots, \mathrm{c}
$$

g. Menghitung fungsi spasial $\left(h_{i k}\right)$

$$
\mathrm{h}_{\mathrm{ik}}=\sum_{\mathrm{z} \in \mathrm{NB}\left(\mathrm{x}_{\mathrm{j}}\right)} \mathrm{u}_{\mathrm{ik}}
$$


h. Perubahan derajat keanggotaan $\left(\mathrm{u}_{\mathrm{ik}}\right)$ menjadi $\left(\mathrm{u}^{\prime}{ }_{\mathrm{ik}}\right)$

$$
\mathrm{u}_{\mathrm{ik}}^{\prime}=\frac{\mathrm{u}_{\mathrm{ik}} \mathrm{p}_{\mathrm{h}_{\mathrm{ik}}} \mathrm{q}^{\mathrm{q}}}{\sum_{\mathrm{k}=1}^{\mathrm{c}} \mathrm{u}_{\mathrm{ik}} \mathrm{p}_{\mathrm{ik}}^{\mathrm{q}}}
$$

i. Menghitung fungsi obyektif $\left(P_{t}\right)$

$$
\mathrm{P}_{\mathrm{t}}=\sum_{\mathrm{i}=1}^{\mathrm{n}} \sum_{\mathrm{k}=1}^{\mathrm{c}}\left(\left[\sum_{\mathrm{j}=1}^{\mathrm{m}}\left(\mathrm{x}_{\mathrm{ij}}-\mathrm{v}_{\mathrm{kj}}\right)^{2}\right]\left(\mathrm{u}_{\mathrm{ik}}\right)^{\mathrm{m}}\right)
$$

Iterasi akan berhenti jika kondisi $\left\|P_{t}-P_{t-1}\right\|<e$ atau $t<$ maksimum iterasi (T) terpenuhi. Apabila iterasi berhenti maka nilai yang diambil adalah nilai $\mathrm{u}_{\mathrm{ik}}$ terakhir (derajat keanggotaan yang optimal). Apabila tidak terpenuhi maka akan mengulang lagi proses menentukan pusat cluster (e)

j. Defuzzifikasi

Defuzifikasi dilakukan untuk mengelompokkan data atau piksel citra kedalam kelompok-kelompok. Berdasarkan derajat keanggotaan $\left(\mathrm{u}_{\mathrm{ik}}\right)$. Penentuan nilai cluster pada setiap data atau piksel bergantung kepada nilai derajat keanggotaan terbesar yang dimilikinya.

Selanjutnya dilakukan tahapan pemotongan citra [6], ekstraksi ciri GLCM [8], dan Ekstraksi ciri HSV [4]. Tahapan cropping citra dapat dilihat pada Gambar 3(a), tahapan ekstraksi ciri GLCM dapat dilihat pada Gambar 3(b), dan tahapan ekstraksi ciri HSV dapat dilihat pada Gambar 3(c).

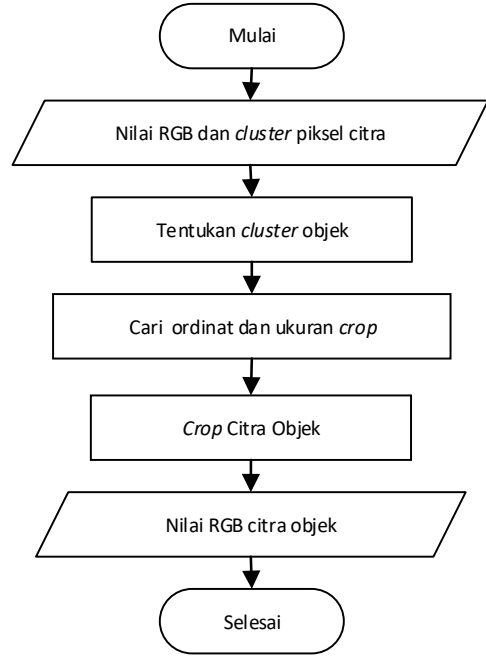

(a)

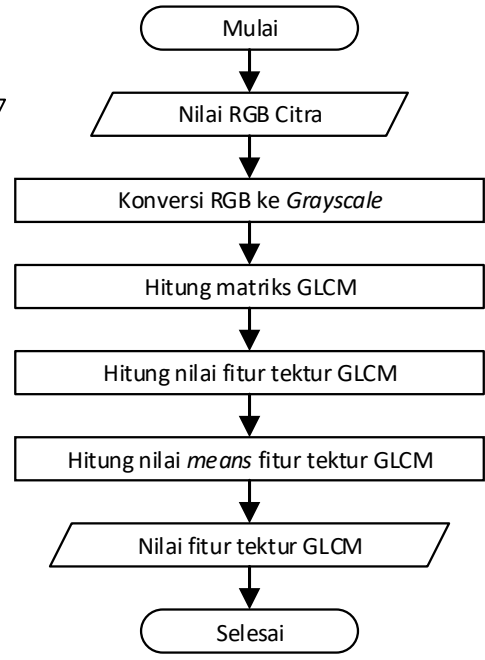

(b)

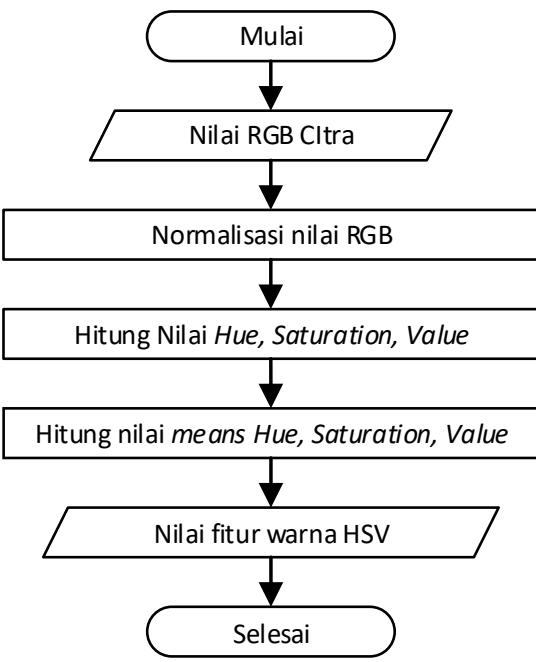

(c)

Gambar 3. (a) Pemotongancitra; (b) Ekstraksi ciri GLCM; (c) Ekstraksi ciri HSV

Untuk algoritma pelatihan menggunakan LVQ3 [10] dapat dilihat pada pseudocode berikut.

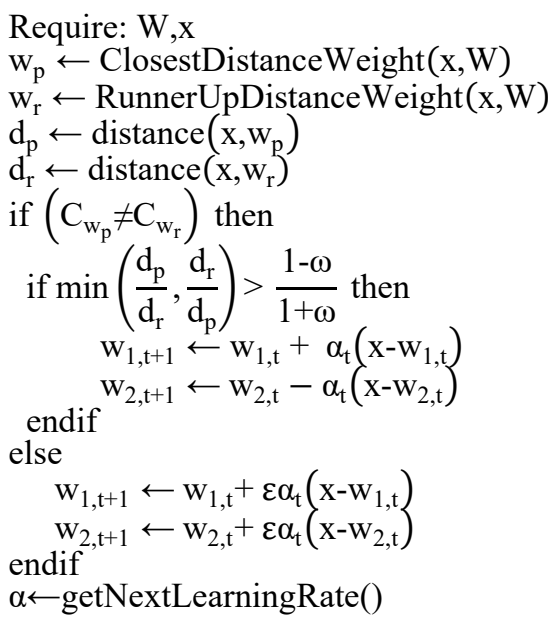


Bobot terus diperbarui sampai batas maksimum iterasi yang ditentukan. Pelatihan menggunakan LVQ3 menghasilkan keluaran bobot optimal yang akan digunakan pada pengujian atau proses klasifikasi. Proses klasifikasi menggunakan perhitungan jarak Euclidean antara antara ciri data uji dengan bobot optimal.

\section{Menghitung Akurasi}

Akurasi didapatkan berdasarkan klasifikasi hasil pengujian. Nilai akurasi dihitung menggunakan Confusion Matrix [11].

\section{HASIL DAN ANALISIS}

Daging oplosan dikategorikan pada citra daging babi, sehingga pembagian data menjadi 60 citra daging sapi dan 60 citra daging babi. Pengujian dilakukan berdasarkan gabungan ekstraksi ciri tekstur dan warna dengan dengan perbandingan data latih dan data uji adalah 108 data : 12 data (90\%: 10) menggunakan konsep confusion matrix. Pengujian menggunakan beberapa nilai parameter learning rate $(\alpha)$ pada proses training yaitu 0,$0001 ; 0,01 ; 0,1 ; 0,4 ; 0,7$; dan 0,9 . Nilai parameter window $(\omega)$ yang digunakan adalah 0,25 dan minimum $\alpha$ yang digunakan adalah 0,001 . Nilai parameter window $(\varepsilon)$ yang digunakan adalah 0,$0001 ; 0,4$ dan 0,7; serta maksimum epoch yang digunakan adalah 1000 iterasi. Sebagai contoh salah satu hasil pengujian dengan nilai $\alpha=0.0001$ dan $\varepsilon=0.0001$ dapat dilihat pada Tabel 1 .

Tabel 1. Hasil akurasi menggunakan confusion matrix

\begin{tabular}{cccc}
\hline & & \multicolumn{3}{c}{ Actual } \\
\hline \multirow{3}{*}{ Predicted } & & Daging Sapi & Daging Babi \\
\cline { 2 - 4 } & Daging Sapi & 6 & 0 \\
\cline { 2 - 4 } & Daging Babi & 1 & 5 \\
\hline
\end{tabular}

Berdasarkan Table 1, hasil prediksi citra daging sapi adalah 6 citra diprediksi sebagai citra daging sapi dan 0 daging babi atau benar semua. Sedangkan hasil prediksi citra daging babi 5 benar dan 1 salah. Berdasarkan data tersebut maka akurasinya adalah sebagai berikut.

$$
\begin{aligned}
& \text { Akurasi }=\frac{\text { Total Prediksi Benar }}{\text { Total Seluruh Pengujian }} \times 100 \% \\
& \text { Akurasi }=\frac{6+5}{6+0+1+5} \times 100 \%=\mathbf{9 1 , 6 7 \%}
\end{aligned}
$$
Gambar 4

Untuk lebih lengkap, hasil pengujian menggunakan beberapa variasi parameter dapat dilihat pada

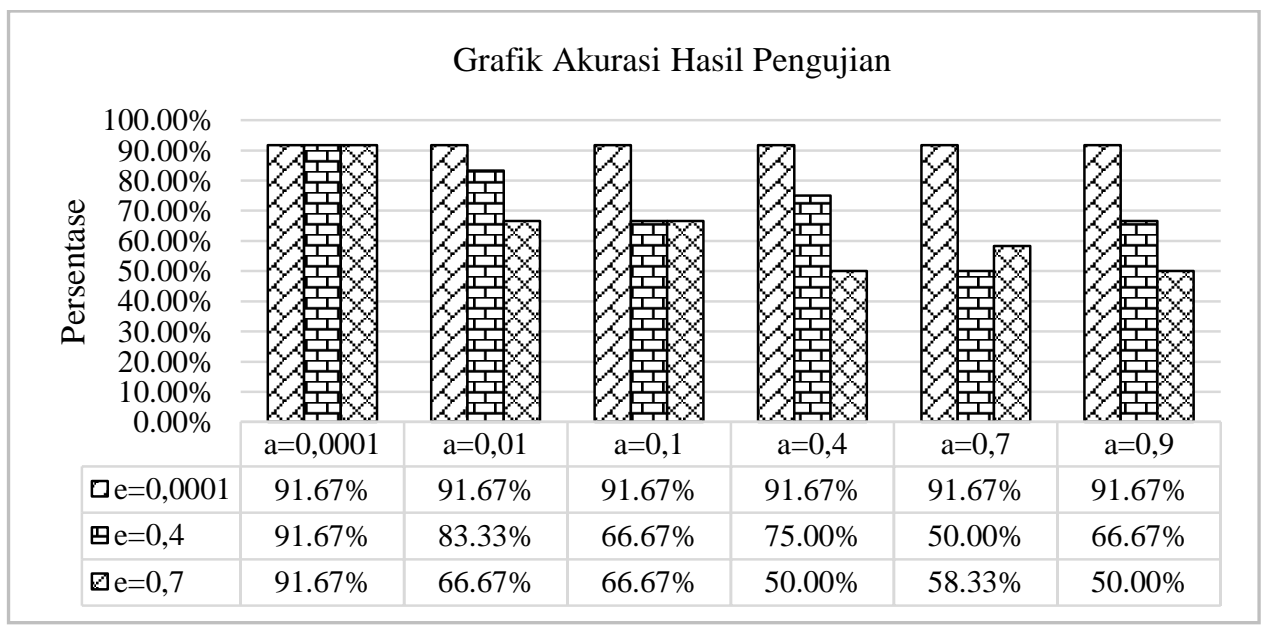

Gambar 4. Akurasi hasil pengujian dengan babarapa variasi parameter

\section{KESIMPULAN}

Penerapan Spatial Fuzzy C-Means pada segmentasi citra dan beberapa proses lainnya seperti cropping area objek, ekstraksi ciri warna HSV dan ekstraksi ciri tektur GLCM citra objek daging serta klasifikasi LVQ3 dapat mengenali citra daging sapi dan citra daging babi dengan persentase nilai akurasi tertinggi 91,67\%. Pada 
penelitian selanjutnya diharapkan dapat memisahkan citra menjadi 3 kelompok yaitu citra daging sapi, citra daging babi dan citra daging oplosan.

\section{REFERENSI}

[1] N. A. Valous, F. Mendoza e P. A. Da-Wen Sun, "Texture appearance characterization of pre-sliced pork ham images using fractal metrics: Fourier analysis dimension and lacunarity," Food Research International, vol. 42, pp. 353-362, 2009.

[2] A. Iqbal, N. A. Valous, F. Mendoza, D.-W. Sun e P. Allen, "Classification of pre-sliced pork and Turkey ham qualities based on image colour and textural features and their relationships with consumer responses," Meat Science, vol. 84, p. 455-465, 2010.

[3] A. F. Hartono, Dwijanto e Z. Abidin, "Implementasi Jaringan Syaraf Tiruan Backpropagation Sebagai Sistem Pengenalan Citra Daging Babi dan Citra Daging Sapi," Unnes Journal of Mathematics, vol. 1, $\mathrm{n}^{\mathbf{o}} 2$, pp. 125-130, 2012.

[4] Kiswanto, E. Sediyono e Suhartono, "Identifikasi Citra Untuk Mengidentifikasi Jenis Daging Sapi Menggunakan Transformasi Wavelet Haar,” Jurnal Sistem Informasi Bisnis, vol. 1, n 2, pp. 73-79, 2014.

[5] Jasril, M. S. Cahyana, L. Handayani e E. Budianita, "Implementasi Learning Vektor Quantization (LVQ) dalam Mengidentifikasi Citra Daging Babi dan Daging Sapi,” em Seminar Nasional Teknologi Informasi, Komunikasi dan Industri (SNTIKI) 7, Pekanbaru, 2015.

[6] D. S. S. Mahdi e R. S. Mahmood, "MR Brain Image Segmentation Using Spatial Fuzzy C- Means Clustering Algorithm," Journal of Engineering, pp. 78-89, 2014.

[7] N. M. Ali, N. K. A. M. Rashid e Y. M. Mustafah, "Performance Comparison between RGB and HSV Color Segmentations for Road Signs Detection," Applied Mechanics and Materials, vol. 393, pp. 550$555,2013$.

[8] R. Listia e A. Harjoko, "Klasifikasi Massa pada Citra Mammogram Berdasarkan Gray Level Cooccurence Matrix (GLCM),” IJCCS, Vol.8, No.1, pp. 59-68, 2014.

[9] E. Budianita e W. Prijodiprodjo, "Penerapan Learning Vector Quantization (LVQ) untuk Klasifikasi Status Gizi Anak," Indonesian Journal of Computing and Cybernetics Systems (IJCCS), vol. 7, $\mathrm{n}^{\circ} 2$, pp. 155-166, 2013.

[10] W. Jatmiko, P. Mursanto, B. Hardian, A. Bowolaksono, B. Wiweko, M. A. Akbar, I. P. Satwika, Z. Immadudin, M. s. Alvissalim, I. Habibie, M. A. Ma'sum e M. N. Kurniawan, Teknik Biomedis: Teori dan Aplikasi, Depok: Fakultas Ilmu Komputer, Universitas Indonesia, 2012.

[11] J. Han, M. Kamber e J. Pei, Data Mining: Concept and Techniques, 3rd ed., USA, 2012.

\section{BIBLIOGRAPHY OF AUTHORS}

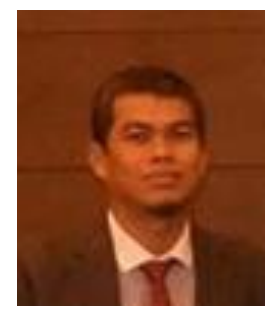

Jasril, S.Si, M.Sc

Penulis adalah pengajar di Program Studi Teknik

Informatika, UIN Sultan Syarif

Kasim Riau

Bidang Keahlian: Artificial

Intelligent, Image Processing

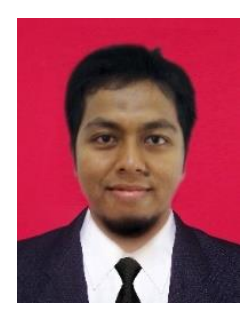

Suwanto Sanjaya, ST, M.Kom

Penulis adalah pengajar di Program Studi Teknik Informatika, UIN Sultan Syarif Kasim Riau Bidang Keahlian : Database System, Image Processing 